\title{
"NEW", UNCONVENTIONAL, TECHNICALLY RECOVERABLE, UNITED STATES GAS RESOURCES FOR THE SHORT TO INTERMEDIATE TERM
}

\author{
by
}

James W. Schmoker and Thaddeus S. Dyman ${ }^{1}$

Open-File Report 96-066

This report is preliminary and has not been reviewed for conformity with U.S. Geological Survey editorial standards and stratigraphic nomenclature.

${ }^{1}$ U.S. Geological Survey, Mail Stop 960

Denver Federal Center, Denver, CO 80225 


\section{INTRODUCTION}

The most recent assessment of United States gas resources for which results are documented by data at the play level is the U.S. Geological Survey (USGS) 1995 National Assessment (Gautier and others, 1995; U.S. Geological Survey National Oil and Gas Resource Assessment Team, 1995). In 1992, a widely recognized United States gas assessment was published by the National Petroleum Council (NPC) (National Petroleum Council, 1992).

The purpose of this report is to quantify new, unconventional, technically recoverable, United States gas resources for the short to intermediate term. As used here, "new" refers to potentially economically viable resources in unconventional gas plays of the USGS 1995 National Assessment that were not recognized by the NPC in their 1992 assessment.

A wellhead price of $\$ 5.00$ per thousand cubic feet $(\mathrm{mcf})$ of gas is considered here to be the highest foreseeable price in the short to intermediate time frame. Therefore, only those USGS unconventional gas plays calculated to have a threshold price at which gas becomes economically recoverable ( $12 \%$ after-tax return) of $\$ 5.00 / \mathrm{mcf}$ or less are considered as possible new gas resources. The analyses of economic viability for gas used here are taken from Attanasi and Rice (1995) and Attanasi and others (1995).

In this report, unconventional gas plays in sandstone, siltstone, shale, and coal (coalbed gas) reservoirs that have a threshold price of $\$ 5.00 / \mathrm{mcf}$ or less are taken from the USGS 1995 National Assessment (Tables 1 and 2). Comparisons are made to the NPC 1992 gas assessment, and new unconventional gas resources relative to the NPC baseline are identified (Table 3).

\section{CONCEPT AND ASSESSMENT OF CONTINUOUS (UNCONVENTIONAL) GAS ACCUMULATIONS}

A new category of unconventional gas play, termed a continuous gas play, was defined for the USGS 1995 National Assessment (Schmoker, 1995). The reservoir rock of a continuous gas play is everywhere charged with gas. For purposes of resource assessment, a continuous gas play is envisioned as a collection of contiguous gas-charged cells.

Continuous gas plays bring together elements of at least four previously recognized unconventional gas categories: 1) basin-center gas, 2) tight gas, 3) shale gas, and 4) coalbed gas. Gas in these categories can be localized in discrete fields, but commonly is pervasive throughout the reservoir formations. For such cases of pervasive gas distribution, the concept of the continuous play represents a synthesis that allows the resources of seemingly diverse types of unconventional gas accumulations to be assessed using a single methodology.

The large volume of gas-charged rocks in continuous accumulations can result in enormous in-place volumes of gas. For example, as much as 5,000 trillion cubic feet (tcf) of gas is locked up in continuous accumulations of the Greater Green River Basin in southwestern Wyoming (Law and others, 1989). However, only a small percentage of this gas is likely to become available for human activity. The USGS 1995 National Assessment estimated technically recoverable gas resources in continuous accumulations, which are much smaller volumes than gas-in-place volumes.

The equating of unconventional gas accumulations to continuous gas accumulations by the USGS is a different approach to resource assessment than that taken by the National Petroleum Council (1992), and could lead to different perceptions of the technically recoverable resources of an accumulation.

Eighty continuous gas plays were described by the USGS 1995 National Assessment, of which 72 were quantitatively assessed. Descriptions of these plays can be found in Rice (1995), 
Schmoker and others (1995), and Schmoker and Oscarson (1995). In the case of the eight plays not assessed, so little data were available for a play that an effort at quantitative assessment could not be defended. Of the assessed continuous gas plays, the predominant reservoir rock is coal for 38 plays, sandstone and siltstone for 26 plays, shale for seven plays, and chalk for one play. This set of continuous plays includes examples of coalbed gas in varied geologic settings, gas in organic-rich self-sourced shale, basin-center gas, gas in formations formally designated by the Federal Energy Regulatory Commission (FERC) as tight, and shallow biogenic gas in lowpermeability chalk and sandstone/siltstone.

Mean potential additions to technically recoverable resources for continuous nonassociated gas plays of the onshore areas and adjoining State waters of the United States total $353 \mathrm{tcf}$ of gas (Gautier and others, 1995). Of this total, $303 \mathrm{tcf}$ is reservoired in sandstone, siltstone, shale, and chalk, and $50 \mathrm{tcf}$ is reservoired in coal. As two points of comparison, proved gas reserves of the United States (excluding Federal waters) total about $135 \mathrm{tcf}$, and United States gas production in 1993 was approximately 21 tcf (American Gas Association, 1994).

A technically recoverable gas volume of $353 \mathrm{tcf}$ is far from trivial. However, continuous gas plays represent disseminated resources for which unit extraction costs are high, analogous in some ways to large, low-grade ore deposits. Some continuous gas plays are of too low quality to be likely to contribute to the supply of natural gas in the short to intermediate term. Of the 34 assessed USGS continuous gas plays in sandstone, siltstone, shale, and chalk reservoirs, only 16 are calculated by Attanasi and others (1995) to have gas available at a threshold price of $\$ 5.00 / \mathrm{mcf}$ or less (Table 1). Of the 38 assessed USGS plays in coal reservoirs, 24 are calculated by Attanasi and Rice (1995) to have gas available at a threshold price of $\$ 5.00 / \mathrm{mcf}$ or less (Table 2). These 40 lower cost plays (Tables 1 and 2) are considered here to be potentially economically viable plays in the short to intermediate term.

\section{NEW UNCONVENTIONAL GAS RESOURCES IN SANDSTONE, SILTSTONE, SHALE, AND COAL RESERVOIRS \\ Sandstone/Siltstone Reservoirs}

For unconventional plays in sandstone/siltstone reservoirs, the NPC estimated large resource volumes, based on their current-technology scenario, in the Piceance Basin (18.5 tcf), Uinta Basin (4.2 tcf), Greater Green River Basin (56.3 tcf), Denver Basin (2.1 tcf), and the Upper Jurassic Cotton Valley Formation of the Gulf Coast Basin (14.0 tcf). In some cases, such as the Cotton Valley Formation, these NPC estimates include FERC-designated tight-sandstone reservoirs that were considered to be conventional (discrete as opposed to continuous) by the USGS.

USGS continuous gas plays and the volumes of gas available at threshold prices of $\$ 5.00 / \mathrm{mcf}$ or less in sandstone/siltstone reservoirs of these basins are (Table 1): Piceance Basin, plays 2007 and 2010 (7.6 tcf); Uinta Basin, plays 2015 and 2016 (0.9 tcf); Greater Green River Basin, plays 3740 and 3741 (4.6 tcf); Denver Basin, play 3906 (0.6 tcf); and Cotton Valley Formation, play 4923 (3.5 tcf). Comparison of the two sets of resource numbers involves the classic "apples and oranges" problem to some degree, accounting for the large numerical differences in some cases. In regard to the objectives of this report, our interpretation is that these USGS plays do not represent new unconventional gas resources relative to the NPC baseline.

The NPC estimated a gas resource of $7.8 \mathrm{tcf}$ for unconventional sandstone plays of the San Juan Basin, whereas 18.3 tcf is estimated to be recoverable at threshold prices of $\$ 5.00 / \mathrm{mcf}$ 
or less from USGS San Juan Basin plays 2205, 2209, and 2211 (Table 1). Envisioning the unconventional basin-center gas accumulation of the San Juan Basin as a group of continuous plays consisting of contiguous cells, many of which remain undrilled, leads to an estimate of 10.5 tcf of new unconventional gas resources relative to the NPC baseline.

In their 1992 study, the NPC credited no unconventional gas resources to biogenic-gas accumulations in shallow, Cretaceous, clastic strata of the Northern Great Plains. Two such continuous USGS plays $(2810,2811)$ are estimated to contain 23.0 tcf of gas that is economically recoverable at threshold prices that do not exceed $\$ 5.00 / \mathrm{mcf}$ (Table 1). Shallow biogenic gas of the Northern Great Plains represents 23.0 tcf of new unconventional gas resources relative to the NPC baseline.

\section{Shale Reservoirs}

For unconventional plays in shale reservoirs, the NPC estimated large resource volumes, based on their current-technology scenario, in the Devonian-Mississippian Antrim Shale of the Michigan Basin (11 tcf) and in Devonian shales of the Appalachian Basin (27 tcf). USGS continuous gas plays and the volumes of gas available at threshold prices of $\$ 5.00 / \mathrm{mcf}$ or less in shale reservoirs of these basins are (Table 1): Antrim Shale, plays 6319 and 6320 (13.6 tcf); and Appalachian Devonian shales, play 6740 (2.7 tcf). Our interpretation is that these USGS plays in shale reservoirs do not represent new unconventional gas resources relative to the NPC baseline. Although the estimate of $13.6 \mathrm{tcf}$ of potentially economically viable gas in Antrim Shale plays 6319 and 6320 (Table 1) is 24 percent higher than the NPC estimate of 11 tcf, this difference is not interpreted here to represent significantly different perceptions of Antrim Shale gas resources, and therefore is not tallied as a new unconventional resource of $2.6 \mathrm{tcf}$.

The USGS and the NPC both considered the Devonian-Mississippian New Albany Shale of the Illinois Basin capable of producing only minor volumes of gas in the short to intermediate term, although current drilling activity targeted for this formation might prove both groups wrong. The USGS 1995 National Assessment estimated undiscovered technically recoverable gas resources (without regard to economic viability) in the New Albany Shale to be 1.9 tcf (play 6407) and in black Devonian shales of the adjoining Cincinnati Arch to be 1.4 tcf (play 6604) (Schmoker and others, 1995).

Limited knowledge of the unconventional gas accumulation in the Mississippian Barnett Shale of the Fort Worth Basin precluded the NPC from assessing this play. The USGS 1995 National Assessment described a Barnett Shale continuous gas play (4503) but did not quantitatively assess the play. However, a search of well-production data on CD-ROM with data current to September, 1995, reveals about 250 productive gas wells in the Barnett Shale. Many of these wells have been drilled since expiration at the end of 1992 of the Section 29

Nonconventional Fuels Tax Credit. This drilling activity strongly suggests that the Barnett Shale play is economically viable at a threshold price of $\$ 5.00 / \mathrm{mcf}$ or less.

The USGS is currently gathering data on the Barnett Shale play. A preliminary estimate by the authors indicates that the continuous gas accumulation in the Barnett Shale represents about $3.4 \mathrm{tcf}$ of new unconventional gas resources relative to the NPC baseline.

\section{Coal Reservoirs}

For unconventional plays in coal reservoirs, the NPC estimated large resource volumes, based on their current-technology scenario, in the Piceance Basin (17 tcf), San Juan Basin (22 tcf), Powder River and Wind River Basins (1 tcf), Raton Basin (5 tcf), Black Warrior Basin (7 tcf), and Northern Appalachian Basin (9 tcf). USGS continuous gas plays and the volumes of gas 
available at threshold prices of $\$ 5.00 / \mathrm{mcf}$ or less in coal reservoirs of these basins are (Table 2): Piceance Basin, plays 2053-2056 (4.9 tcf); San Juan Basin, plays 2250, 2252, and 2253 (6.5 tcf); Powder River and Wind River Basins, plays 3350 and 3550 (0.9 tcf); Raton Basin, plays 41504152 (1.6 tcf); Black Warrior Basin, play 6551 (1.2 tcf); and Northern Appalachian Basin, play 6750 ( $0.5 \mathrm{tcf})$. Except for the combined Powder River and Wind River Basins, the USGS estimates of potentially economically viable coalbed-gas resources (Table 2) are much lower than the NPC estimates. These continuous USGS coalbed-gas plays do not represent new unconventional gas resources relative to the NPC baseline.

The NPC estimated a coalbed-gas resource of 1 tcf for the Uinta Basin and $1 \mathrm{tcf}$ for the Greater Green River Basin, whereas $1.8 \mathrm{tcf}$ and $2.1 \mathrm{tcf}$ are estimated to be recoverable at threshold prices of $\$ 5.00 / \mathrm{mcf}$ or less from USGS Uinta Basin plays 2050 and 2052 and Greater Green River Basin plays 3750,3752, and 3753, respectively (Table 2). These comparisons yield a volume of 1.9 tcf of new unconventional gas resources relative to the NPC baseline.

Lesser known coalbed-gas provinces studied by the NPC but considered by them to be of low resource potential and not formally assessed include the Cherokee and Forest City Basins, Central Appalachian Basin, Cahaba Coal Field (Appalachian Basin), Puget Downwarp of Western Washington, Illinois Basin, and Arkoma Basin. The USGS also studied these lesser known coalbed-gas provinces and concluded that some of them might have significant economically viable coalbed-gas resources. As shown by Table 2, estimates of gas available from continuous USGS plays in lesser known coalbed-gas provinces, at threshold prices that do not exceed $\$ 5.00 / \mathrm{mcf}$, are $0.3 \mathrm{tcf}$ from play 451 in Western Washington, 2.0 tcf from plays 6250 and 6251 in the Arkoma Basin, $1.3 \mathrm{tcf}$ from play 6450 in the Central Illinois Basin, and $2.5 \mathrm{tcf}$ from play 6752 in the Central Appalachian Basin. Taken together, these plays provide $6.1 \mathrm{tcf}$ of new unconventional gas resources relative to the NPC baseline.

\section{SUMMARY}

The purpose of this report is to quantify new, unconventional, technically recoverable, United States gas resources for the short to intermediate term. As used here, "new" refers to potentially economically viable resources in unconventional (continuous) gas plays of the USGS 1995 National Assessment (Gautier and others, 1995) that were not recognized by the NPC in their 1992 assessment (National Petroleum Council, 1992).

This study identifies 44.9 tcf of new unconventional gas resources relative to the NPC baseline, as summarized in Table 3. Of these new resources, 33.5 tcf or 74 percent of the total occur in sandstone and siltstone reservoirs of the San Juan Basin and Northern Great Plains; 3.4 tcf or 8 percent of the total occur in the Barnett Shale of the Fort Worth Basin; and 8.0 tcf of 18 percent of the total are distributed among coal reservoirs of six different basins. 


\section{REFERENCES CITED}

American Gas Association, 1994, Gas facts, 1993 data: American Gas Association, Arlington, Virginia, $206 \mathrm{p}$.

Attanasi, E.D., and Rice, D.D., 1995, Economics and coalbed gas in the 1995 National Assessment of U.S. oil and gas resources: U.S. Geological Survey Open-File Report 95$75 \mathrm{~A}, 22 \mathrm{p}$.

Attanasi, E.D., Schmoker, J.W., and Quinn, J.C., 1995, Economics and continuous-type oil and gas accumulations in the 1995 National Assessment of U.S. oil and gas resources: U.S. Geological Survey Open-File Report 95-75F, 35 p.

Gautier, D.L., Dolton, G.L., Takahashi, K.I., and Varnes, K.L., eds., 1995, 1995 National Assessment of United States oil and gas resources -- Results, methodology, and supporting data: U.S. Geological Survey Digital Data Series DDS-30 [CD-ROM].

Law, B.E., Spencer, C.W., Charpentier, R.R., Crovelli, R.A., Mast, R.F., Dolton, G.L., and Wandrey, C.J., 1989, Estimates of gas resources in overpressured low-permeability Cretaceous and Tertiary sandstone reservoirs, Greater Green River Basin, Wyoming, Colorado, and Utah, in Eisert, J.L., ed., Gas resources of Wyoming: Wyoming Geological Association Guidebook, Fortieth Field Conference, Casper, Wyoming, p. 3961.

National Petroleum Council, 1992, The potential for natural gas in the United States -- source and supply: National Petroleum Council, Washington, D.C., 501 p.

Rice, D.D., 1995, Geologic framework and description of coalbed gas plays, in Gautier, D.L., Dolton, G.L., Takahashi, K.I., and Varnes, K.L., eds., 1995 National Assessment of United States oil and gas resources -- Results, methodology, and supporting data: U.S. Geological Survey Digital Data Series DDS-30 [CD-ROM].

Schmoker, J.W., 1995, Method for assessing continuous-type (unconventional) hydrocarbon accumulations, in Gautier, D.L., Dolton, G.L., Takahashi, K.I., and Varnes, K.L., eds., 1995 National Assessment of United States oil and gas resources -- Results, methodology, and supporting data: U.S. Geological Survey Digital Data Series DDS-30 [CD-ROM].

Schmoker, J.W., Crovelli, R.A., and Balay, R.H., 1995, Potential additions to technically recoverable resources for each continuous-type (unconventional) play of the U.S. Geological Survey 1995 National Assessment of United States oil and gas resources -graphical and tabular presentations: U.S. Geological Survey Open-File Report 95-75E, 58 p.

Schmoker, J.W., and Oscarson, S.A., 1995, Descriptions of continuous-type (unconventional) plays of the U.S. Geological Survey 1995 National Assessment of United States oil and gas resources: U.S. Geological Survey Open-File Report 95-75B, 44 p.

U.S. Geological Survey National Oil and Gas Resource Assessment Team, 1995, 1995 National Assessment of United States oil and gas resources: U.S. Geological Survey Circular $1118,20 \mathrm{p}$. 
Table 1. Unconventional (continuous) gas plays assessed by the USGS 1995 National Assessment, in sandstone, siltstone, and shale reservoirs, that have a threshold price of $\$ 5.00 / \mathrm{mcf}$ or less. Data are from Gautier and others (1995) and Attanasi and others (1995).

PLAY NUMBER AND DESCRIPTION
UNDISCOVERED, TECHNICALLY RECOVERABLE GAS RESOURCES (TCF)

Total for Play Available at Threshold Price

2007 Mesaverde (Williams Fork), Piceance Basin

2010 Mesaverde (Iles), Piceance Basin

4.87

4.83

3.87

2015 Tertiary east, Uinta Basin

2.14

0.51

8.21

9.58

3.26

5.44

20.48

37.25

51.71

0.83

6.03

4.93

13.94

9.10

183.11
3.75

0.74

0.13

7.50

8.14

2.67

4.38

18.59

1.35

3.27

0.61

3.48

3.98

9.62

2.74

74.82 
Table 2. Unconventional (continuous) gas plays assessed by the USGS 1995 National Assessment, in coal reservoirs, that have a threshold price of $\$ 5.00 / \mathbf{m c f}$ or less. Data are from Gautier and others (1995) and Attanasi and Rice (1995).

PLAY NUMBER AND DESCRIPTION
UNDISCOVERED, TECHNICALLY RECOVERABLE GAS RESOURCES (TCF)

Available at Threshold Price

0451 Western Cascade Mountains, Washington

0.54

0.33

2050 Book Cliffs, Uinta Basin

1.94

1.22

2052 Wasatch Plateau-Emery, Uinta Basin

0.75

0.55

2053 White River Dome, Piceance Basin

0.33

0.18

2054 Western margin, Piceance Basin

6.49

4.23

2055 Grand Hogback, Piceance Basin

0.24

0.19

2056 Divide Creek Anticline, Piceance Basin

0.40

0.26

2250 Overpressured area, San Juan Basin

4.16

3.33

2252 Underpressured discharge area, San Juan Basin

2.14

2.10

2253 Underpressured area, San Juan Basin

1.22

1.04

3350 Mining related, Powder River Basin

0.68

0.53

3550 Mesaverde, Wind River Basin

0.43

0.35

3750 Rock Springs Uplift, Greater Green River Basin

0.69

0.58

3752 Mesaverde (Williams Fork), Greater Green River Basin

1.38

0.98

3753 Mesaverde (Almond), Greater Green River Basin

0.80

0.57

4150 Northern portion, Raton Basin

0.91

0.86

4151 Purgatoire River, Raton Basin

0.29

0.25

4152 Southern portion, Raton Basin

0.57

0.53

6250 Anticline, Arkoma Basin

0.38

0.27

6251 Syncline, Arkoma Basin

2.26

1.75

6450 Central portion, Illinois Basin

1.63

1.34

6551 Southeast portion, Black Warrior Basin

1.31

1.20

6750 Anticline, northern Appalachian Basin

1.07

0.45

6752 Central portion, Appalachian Basin 
Table 3. New, short to intermediate term, unconventional, technically recoverable, United States gas resources. Play numbers refer to the USGS 1995 National Assessment (Gautier and others, 1995).

\section{GAS}

RESOURCES (TCF)

\section{DESCRIPTION}

10.5 Dakota, Mesaverde, and Pictured Cliffs formations (sandstone/siltstone) of San Juan Basin (plays 2205, 2209, 2211).

23.0 Biogenic gas in shallow Cretaceous strata (sandstone/siltstone) of Northern Great Plains (plays 2810, 2811).

3.4* Barnett Shale (organic-rich shale) of Fort Worth Basin (play 4503).

1.9 Book Cliffs and Wasatch Plateau-Emery areas (coal) of Uinta Basin (plays 2050, 2052); Rock Springs Uplift and Mesaverde Group (coal) of Greater Green River Basin (plays 3750, 3752, 3753).

6.1 Lesser known coalbed-gas provinces: Western Washington (play 451); Arkoma Basin (plays 6250, 6251); Central Illinois Basin (play 6450); Central Appalachian Basin (play 6752).

$\overline{44.9}$

* Gas resource for Barnett Shale is an unpublished estimate based on work in progress by the authors. 